\title{
Genistein promotes cell death of ethanol-stressed HeLa cells through the continuation of apoptosis or secondary necrosis
}

\author{
Xin Xie ${ }^{\dagger}$, Shan Shan Wang ${ }^{\dagger}$, Timothy Chung Sing Wong and Ming Chiu Fung
}

\begin{abstract}
Background: Apoptosis is a major target and treatment effect of multiple chemotherapeutical agents in cancer. A soybean isoflavone, genistein, is a well-studied chemopreventive agent and has been reported to potentiate the anticancer effect of some chemotherapeutics. However, its mechanistic basis of chemo-enhancement effect remains to be fully elucidated.

Methods: Apoptotic features of low concentration stressed cancer cells were studied by microscopic method, western blot, immunostaining and annexin V/PI assay. Genistein's effects on unstressed cells and recovering cells were investigated using MTT cell viability assay and LDH cytotoxicity assay. Quantitative real-time PCR was employed to analyze the possible gene targets involved in the recovery and genistein's effect.

Results: Low-concentration ethanol stressed cancer cells showed apoptotic features and could recover after stress removal. In stressed cells, genistein at sub-toxic dosage promoted the cell death. Quantitative real-time PCR revealed the up-regulation of anti-apoptotic genes MDM2 and XIAP during the recovery process in HeLa cells, and genistein treatment suppressed their expression. The application of genistein, MDM2 inhibitor and XIAP inhibitor to the recovering HeLa cells caused persistent caspase activity and enhanced cell death. Flow cytometry study indicated that genistein treatment could lead to persistent phosphatidylserine (PS) externalization and necrotic events in the recovering HeLa cells. Caspase activity inhibition shifted the major effect of genistein to necrosis.

Conclusions: These results suggested two possible mechanisms through which genistein promoted cell death in stressed cancer cells. Genistein could maintain the existing apoptotic signal to enhance apoptotic cell death. It could also disrupt the recovering process in caspase-independent manner, which lead to necrotic events. These effects may be related to the enhanced antitumor effect of chemotherapeutic drugs when they were combined with genistein.
\end{abstract}

Keywords: Genistein, HeLa Cell, Stress Recovery, Apoptosis, Necrosis

\section{Background}

Conventional chemotherapeutic agents were screened or developed based on the feature that tumor cells usually proliferate faster than normal cells [1,2]. By interacting with different intracellular targets such as DNA molecules or microtubules, chemotherapeutics introduce various degrees of damage or stress in rapidly dividing cells, leading to toxic effects $[3,4]$. Although the molecular

\footnotetext{
*Correspondence: mingchiufung@cuhk.edu.hk

${ }^{\dagger}$ Equal contributors

School of Life Sciences, the Chinese University of Hong Kong, Room EG07, Shatin, New Territory, Hong Kong, SAR, China
}

details responsible for their anti-cancer effects were not fully unveiled, most anti-cancer drugs exert their toxicity through apoptotic cell death [3-5]. The significance of apoptosis in tumorigenesis and chemotherapy is further underpinned by frequent mutations of genes involved in apoptotic initiation and execution, and defects in apoptosis may impair treatment effect [6,7]. The findings that chemo-resistance of cancer cells is often associated with defective apoptosis makes the restoration of effective apoptosis a potential therapeutic improvement, either through suppressing anti-apoptotic functions or restoring the pro-apoptotic activities $[8,9]$.

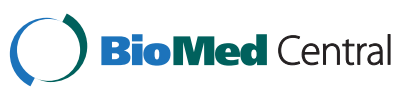


Genistein is a predominant soybean isoflavone whose anti-cancer effects have been intensively studied. Epidemiological studies suggested that the lower incidence of prostate and breast cancer in Asian, when compared to western countries, could be attributed to the rich isoflavonoid content found in Asian diets-including genistein [10-12]. Both in vitro and in vivo analyses showed that genistein inhibits the growth of various cancer cells at doses non-toxic to normal cells [13-15]. In terms of its known molecular targets in cancer cells, genistein was proved to be a competitive inhibitor for estrogen receptor, interfere signal transduction by inhibiting the activity of protein tyrosine kinase, suppress angiogenesis, and arrest cell cycle at $\mathrm{G}_{2}-\mathrm{M}$ transition [16-18]. The investigation of gene expression profile of genistein-treated prostate cancer cells also revealed that genistein could regulate the expression of genes involved in various cell processes such as proliferation, cell cycle progression, transcription, apoptosis, oncogenesis, angiogenesis, and cancer cell invasion and metastasis $[19,20]$. Besides, increasing number of research indicated that genistein promoted the anti-tumor effect of chemotherapeutics towards multiple types of tumors, implying that genistein could be a useful chemopreventive agent [21-23]. However, the mechanistic basis for its chemo-enhancement effect remains to be fully characterized.

In this study, we investigated the effect of genistein on low concentration ethanol- stressed HeLa cells with apoptotic features. Stressed HeLa cells could recover after replacing the ethanol-containing medium with fresh medium. We found that genistein promoted the cell death of stressed HeLa cells at the concentration without detectable toxicity to untreated cells. The death-promoting effect might result from the suppression of anti-apoptotic genes including $M D M 2$ and XIAP, which were up-regulated during recovery process after stress removal. Similar to genistein's effect, the inhibition of XIAP and MDM2 protein activity resulted in persistent caspase- 3 activity and enhanced cell death in the recovering HeLa cells. Nevertheless, the application of caspases inhibitor did not rescue the recovering cells from the death-promoting effect of genistein. Collectively, our data provided evidence on the death-potentiating effect of genistein on stressed HeLa cells through caspase- dependent or independent way.

\section{Results}

Low concentration ethanol stressed HeLa cells displayed apoptotic features and the stressed cell could recover after stress removal

We initially aimed to set up stressed condition that could initiate apoptotic features in HeLa cells. Ethanolinduced hepatic apoptosis has been widely reported in experimental trials with different animals and clinical alcoholic diseases [24]. However, the toxic effects of ethanol correlate with the applied concentrations and exposure time. High concentrations of ethanol could cause necrotic cell death [25]. Low concentration ethanol treatment was reported to induce apoptosis in HepG2 cells, and both fas- and cytochrome C-mediated pathway may be involved $[24,25]$. In human intestinal Caco-2 cell line, treatment with $10 \%$ ethanol up to 3 hours could lead to considerable PS externalization. Caspase-mediated CK18 cleavage and DNA fragmentation was detected after 2 hours' treatment [26].

We optimized the ethanol (stress) concentration and exposure time used to stress HeLa cells. Incubation in ethanol-containing medium $(5.5 \%, \mathrm{~V}: \mathrm{V})$ up to 8 hours (E8hrs) caused significant cellular shrinkage while the shrunken cells regained normal morphology after replacing stressed medium with fresh culture medium (E8 hrs + R24 hrs) (Figure 1a). Nuclear condensation and the disruption of mitochondrial network were observed, which were reversible after the removal of stress (Figure 1a).

In addition to morphological changes, biochemical markers of apoptosis were investigated. Western blot and caspase-3 immunostaining results showed the cleavage of biochemical marker caspase- 3 and its substrate PARP in the stressed cells (Figure 1b, c: E6 hrs \& E8 hrs). The activation of caspase-7 and -9 were also detected (Figure 1b). The disappearance of cleaved caspases and PARP after 24 hours' recovery (E8 hrs + R24 hrs) indicated that apoptotic signals could be terminated and eliminated in the absence of continuous stress. Furthermore, Annexin V and PI staining assay revealed the loss of membrane asymmetry after stress treatment in the form of phosphatidylserine (PS) externalization (Figure 2e, E8 hrs), and the gradual restoration of membrane asymmetry after stress removal (Figure 2e, E8 hrs + R12 hrs \& E8 hrs + R24 hrs). The gradual increase of annexin V signal intensity with the ethanol stress time was consistent with previous study concerning ethanol-induced apoptosis in Caco-2 cells [26], which seems to be a concentration- and time-dependent process. Collectively, our results demonstrated the ethanol-stressed apoptotic features, including morphological and biochemical alterations, were reversible in HeLa cells. The optimized stress conditions $(5.5 \%$ ethanol $8 \mathrm{hrs}$ for HeLa), on which most cells displayed reversible changes, were used for the following study.

\section{At sub-toxic concentration, genistein promoted the cell death of stressed HeLa cells after the removal of ethanol} Based on the optimized stress conditions, we compared the dose-responsive curves of genistein between stress and unstressed cells using MTT assay. Stressed HeLa cells were more sensitive to genistein treatment than unstressed ones, manifested by the left shift of dose-response curve of stressed group (Figure 2a, $p<0.01$ by two-way ANOVA) 


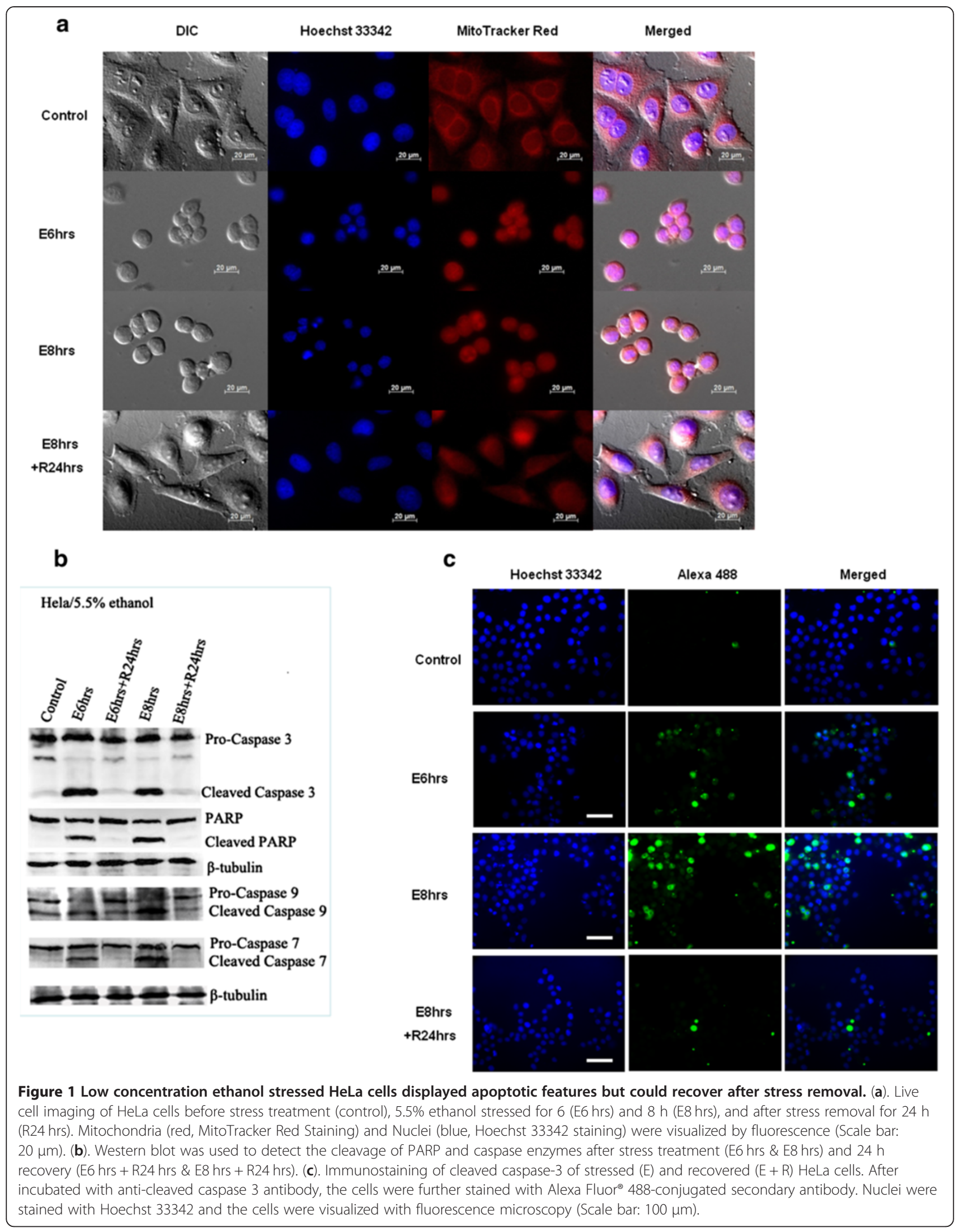




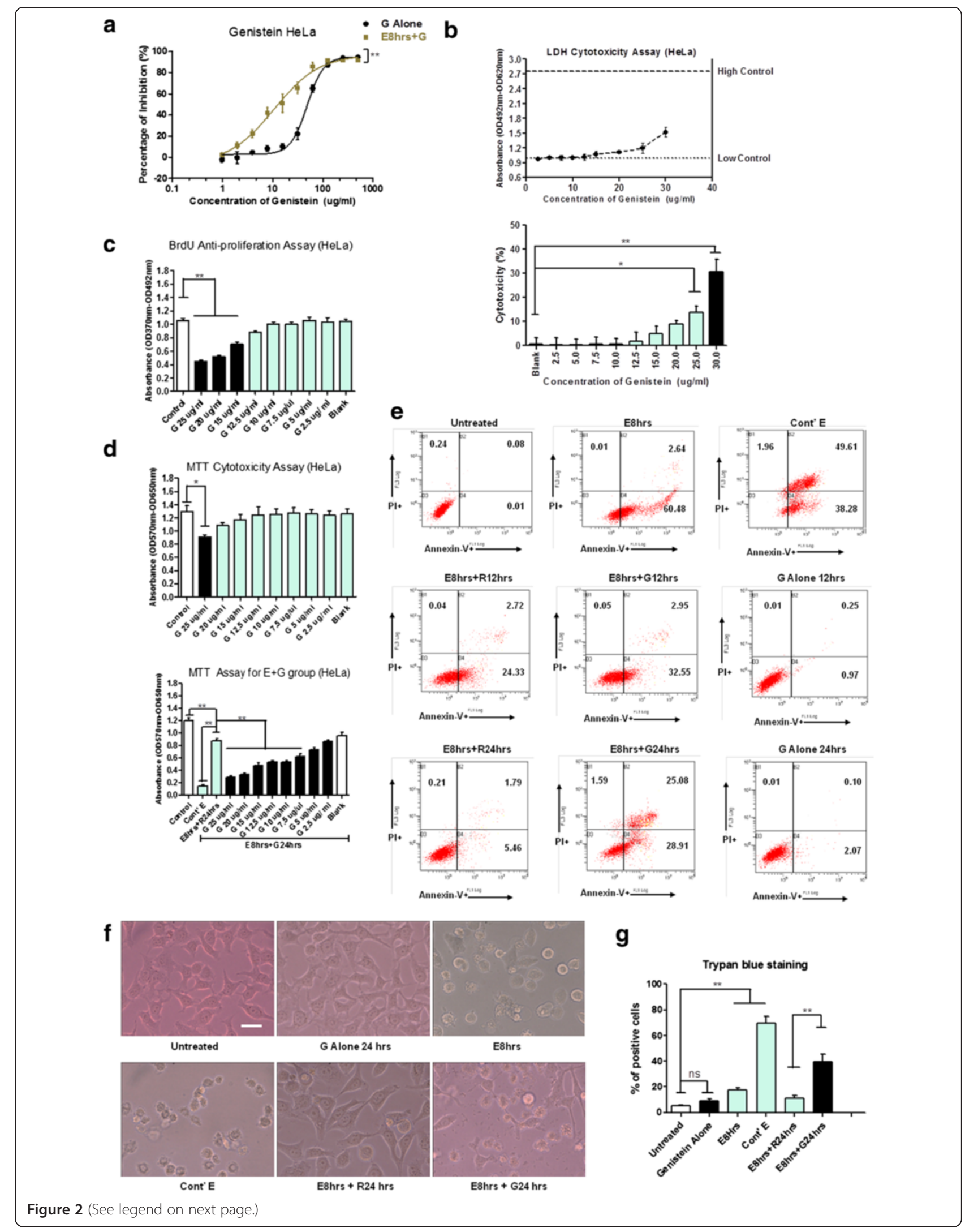




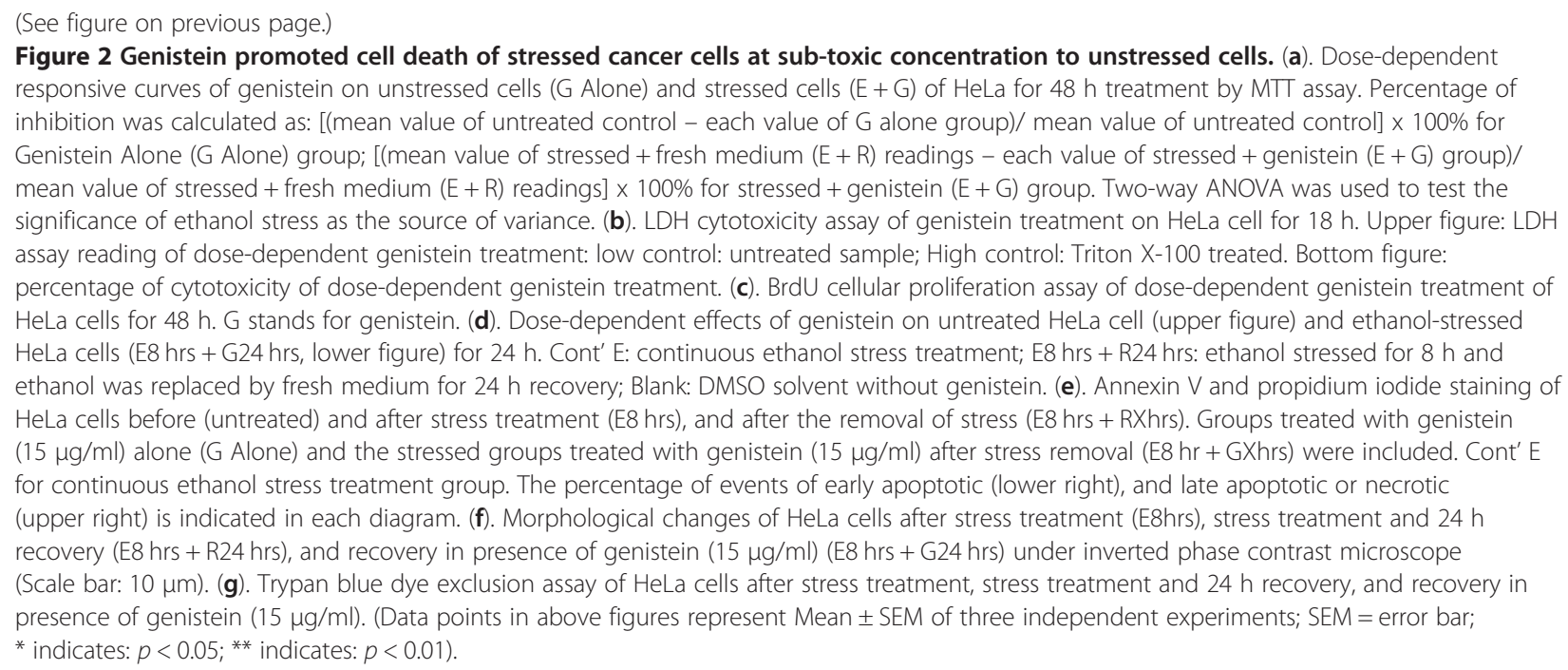

and its lower IC50 value (concentration of genistein with $50 \%$ inhibitory effect: $48.55 \mu \mathrm{g} / \mathrm{ml}$ for unstressed cells; $10.53 \mu \mathrm{g} / \mathrm{ml}$ for stressed cells). To exclude the effect of direct cytotoxicity and anti-proliferation of genistein, we then detected the cytotoxic range of genistein by lactate dehydrogenase release assay and its effective dose of anti-proliferation effect by BrdU incorporation assay. The death-promoting effect of genistein on stressed HeLa cells existed at the concentration $(10 \mu \mathrm{g} / \mathrm{ml})$ where there were no detectable cytotoxicity to unstressed group (Genistein $\geq 25 \mu \mathrm{g} / \mathrm{ml}$ to be cytotoxic in HeLa cells) and anti-proliferative effects (Genistein $\geq 15 \mu \mathrm{g} / \mathrm{ml}$ to show detectable anti-proliferation effect in HeLa cells) (Figure 2b, c, d). Below the threshold of cytotoxicity, $10 \mu \mathrm{g} / \mathrm{ml}$ genistein treatment significantly reduced MTT reading of stressed cells, compared to the MTT reading of stressed cells with fresh medium replacement only (Figure $2 \mathrm{~d}, p<0.01$ ).

We further applied Annexin-V and PI staining assay to investigate genistein's effect quantitatively. Flow cytometry results demonstrated that genistein treatment (at concentration $15 \mu \mathrm{g} / \mathrm{ml}$, no cytotoxicity effect) inhibited the membrane asymmetry restoration of stressed cells (E8 hrs + G12 hrs \& E8 hrs + G24 hrs), while genistein treatment on unstressed cells showed no significant effect (G Alone $24 \mathrm{hrs}$ ) (Figure 2e). In the presence of genistein (E8 hrs + G24 hrs), Annexin V single-positive cells persisted and the percentage of Annexin V/PI double-positive cells increased in the stressed cell population, indicating pleiotropic effects of genistein on the recovery from stress. The cellular morphologies in different experimental groups were showed in Figure 2f, which was consistent with the flow cytometry data to show the death-promoting effect of genistein on the stressed cells. Trypan blue dye exclusion assay was used to quantify the terminally dead cells which are permeable to the dye. The results further verified that the genistein promoted the death of stressed cells which was undergoing the recovery process (Figure $2 \mathrm{~g}$ ).

\section{Genes involved in recovery of stress treatment were influenced by genistein}

To study the mechanism of the recovery from stress and the death-promoting effect of genistein, we first compared the sensitivity difference to transcription and translation inhibitor (Actinomycin D and Cycloheximide) between stress and unstressed HeLa cells. Dose-responsive curve indicated stressed cells undergoing recovery process were more sensitive to transcription and translation inhibition (Figure 3a, $p<0.01$ by two-way ANOVA). We then collected mRNA samples of HeLa cells at different time points after the removal of stress in the absence or presence of genistein, including the group treated with genistein alone (Figure 3b). Quantitative real-time PCR was applied to determine the mRNA level of genes relevant to apoptosis or survival. Among the genes investigated, ATF3, CREB1, $X I A P, M D M 2$ and MCL1 were involved in the recovery period, which were up-regulated after the stress removal and then gradually returned to the level of untreated control (Figure 3c, statistical comparison of each time point between Wash + Fresh Medium and Wash + Genistein group by tow-way ANOVA, * indicates: $p<0.05$; *** indicates: $p<0.01)$. Genistein treatment interfered with the expression profiles of ATF3, XIAP, MDM2 and MCL1 genes during recovery phase. Genistein delayed the decrease of ATF3 and MCL1 expression, but attenuated up-regulation of XIAP and $M D M 2$ in the group undergoing recovery, while genistein treatment alone to unstressed group did not have that effect (Figure 3c). Other genes including TP53, NOXA, PUMA did not seem to be regulated during the recovery period after stress removal. 


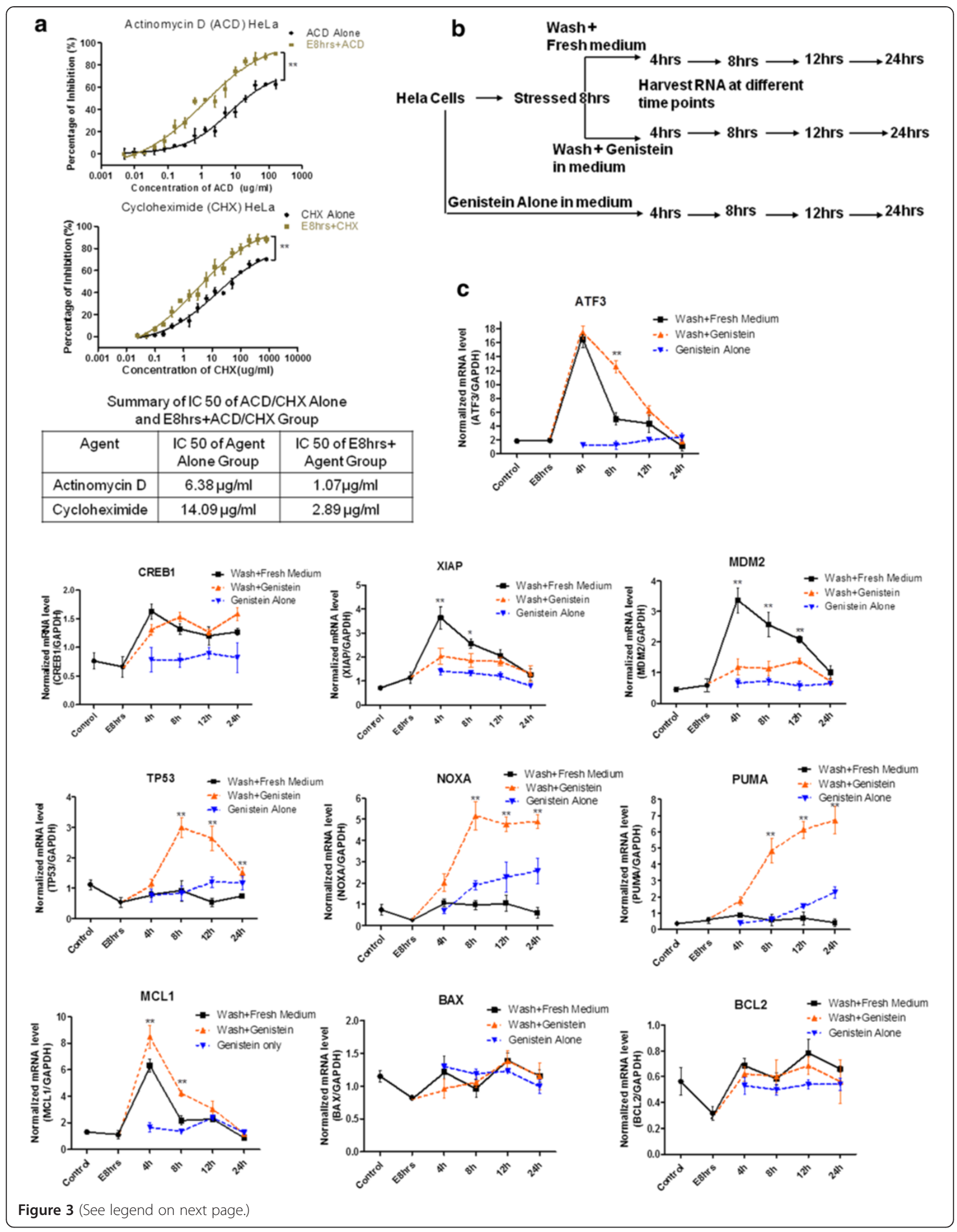


(See figure on previous page.)

Figure 3 Genes involved in the recovery from stress treatment were influenced by genistein. (a). Dose-dependent responsive curves of Actinomycin D and Cycloheximide on unstressed cells (ACD Alone and CHX Alone) and stressed cells (E8 hrs + ACD and E8 hrs + CHX) of HeLa for $48 \mathrm{~h}$ treatment by MTT assay. Two-way ANOVA was used to test the significance of ethanol stress as the source of variance. IC50 of each group is summarized in table. (b). Schematic schedule of RNA sample collection for each treatment group, including genistein treatment alone, stressed and replaced with fresh medium for recovery, and stressed and replaced with genistein-containing medium. (c). Time-dependent gene expression profiles of ATF3, CREB1, XIAP, MDM2, TP53, NOXA, PUMA, MCL1, BAX, BCL2, in different groups of HeLa cell. Control stands for the untreated cells; E8 hrs represents ethanol-stressed cells for 8 hrs; Black line: ethanol-stressed and stress replaced with fresh medium; Orange line: ethanol-stressed and stress replaced with medium containing $15 \mu \mathrm{g} / \mathrm{ml}$ genistein. Blue line: unstressed cells treated with $15 \mu \mathrm{g} / \mathrm{ml} \mathrm{genistein.} \mathrm{Each} \mathrm{gene} \mathrm{expression} \mathrm{level} \mathrm{is}$ normalized to that of GAPDH. (Data point above is expressed as Mean $\pm S E M, n=3$; asterisk indicates statistical comparison of each time point between Wash + Fresh Medium and Wash + Genistein group by tow-way ANOVA, ${ }^{*}$ indicates: $p<0.05 ;{ }^{* *}$ indicates: $\left.p<0.01\right)$.

However, genistein treatment dramatically increased their expression levels after the removal of stress. The third group of genes such as $B C L 2$ and $B A X$ did not seem to play significant part in the recovery and in the genistein treatment group. Overall, the gene expression profiles demonstrated differential gene expressions in the recovery from stress treatment and the influence of genistein on their regulations. XIAP and MDM2 genes, whose expressions were up-regulated in the recovery process and attenuated in the presence of genistein, were subject to further investigation.

\section{Similar to genistein, MDM2 and XIAP inhibitor potentiated the cell death and caused persistent caspase- 3 activity in recovering cells}

To confirm the roles of MDM2 and XIAP in the recovery of stressed cells, we first compared the sensitivity of stressed cells and unstressed cells to MDM2 inhibitor (Boranyl-chalcone) and XIAP inhibitor (Embelin). IC50 difference (Figure 4a, table) indicated that HeLa cells undergoing recovery are highly dependent on MDM2 and XIAP activity. XIAP and MDM2 inhibitor treatment suppressed the regaining of normal morphology of stressed cells after stress removal (Figure 4b). MTT and Trypan blue assay demonstrated that XIAP and MDM2 inhibition caused further loss of cellular viability and enhanced cell death to the recovering cells at the concentration where there were no significant effects to unstressed cells (Figure 4c). More importantly, western blot and immunostaining results revealed that after the removal of stress, apoptotic marker like cleaved caspase 3 and PARP persisted in the recovering HeLa cells in the presence of genistein, XIAP and MDM2 inhibitor (Figure 4d, e). These data suggested that genistein might enhance the cell death of stressed HeLa cells by continuing the existing apoptotic signal or by preventing the clearance of activated caspases, possibly through the interference with MDM2 and XIAP expression.

\section{The death-promoting effect by genistein could be caspase-independent}

Now that apoptotic signal like cleaved caspase 3 persisted in the recovering cells when genistein was present, we further applied general caspase inhibitor to investigate whether the caspase activity inhibition could rescue genistein's death-enhancing effect on the stressed HeLa cells. General caspase inhibitor Z-VAD-fmk effectively blocked caspase activity at the concentration of $100 \mu \mathrm{M}$, manifested by the great reduction of cleaved PARP (Figure 5a). Through MTT viability assay, the addition of Z-VAD-fmk did not rescue the death-promoting effects of genistein on the recovering cells, which indicated that genistein's effect was not restricted to the enduring and potentiation of apoptotic signal (Figure $5 b$ ).

\section{Caspase inhibition shifted genistein's action profile}

Another question to be considered was what are other factors contributing to genistein's effect in the recovering HeLa cells? Using Annexin V/PI staining assay, we observed that caspase activity inhibition contributed little to the recovery process after the stress removal (Figure 6c). However, the addition of caspase inhibitor significantly altered the profile of genistein's effect by a great percentage shift from Annexin V single positive cells to Annexin V/PI double-positive cells after 24 hours (Figure 6c: E8 hrs + G24hrs \& E8 hrs + G\&Z-VAD24hrs). These changes were further manifested by the increase of cells displaying necrotic features in the presence of both genistein and Z-VAD-fmk (Figure 6a: E8 hrs + G\&Z-VAD24 hrs), compared to the group with genistein treatment only (Figure 6a: E8 hrs + G24 hrs). Trypan blue staining showed consistent result that significant increase of cells losing homeostasis control in genistein treatment group in the presence of caspase inhibitor Z-VAD-fmk (Figure 6b). Together, these results implied that genistein could also influence other cellular recovery processes and disrupt the homeostasis maintenance of stressed cells to cause necrosis which is secondary to the primary apoptotic program.

\section{Discussion}

Low concentration of ethanol has been reported to induce apoptosis in animal and cell line models [24-26]. Ethanolinducible Cytochrome-P4502E1 (CYPE gene product) may contribute to the death signal by producing reactive oxygen species [27]. In this study, we optimized ethanol treatment condition in HeLa cell line. We provided 
a
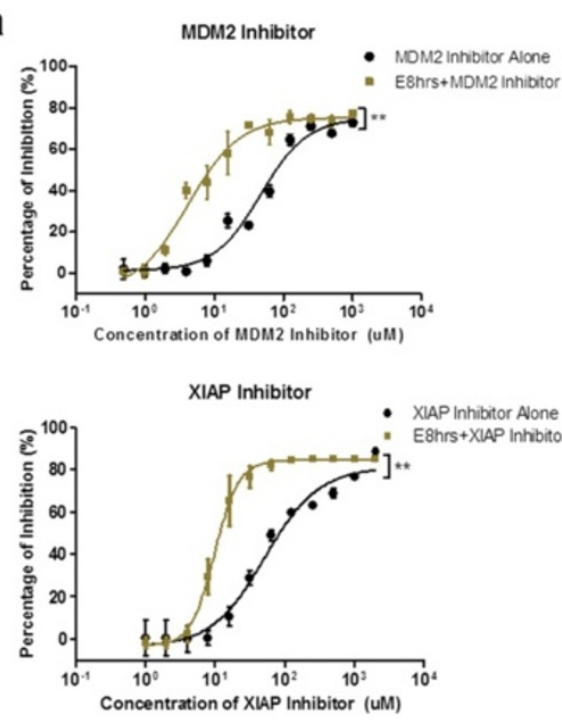

Summary of IC50 of MDM2/XIAP inhibitor alone and \begin{tabular}{|c|c|c|}
\hline \multicolumn{3}{|c|}{ E8hrs+MDM2/XIAP inhibitor } \\
\hline Agent & $\begin{array}{c}\text { IC } 50 \text { of Agent } \\
\text { Alone Group }\end{array}$ & $\begin{array}{c}\text { IC } 50 \text { of E8hrs+ } \\
\text { Agent Group }\end{array}$ \\
\hline MDM2 Inhibitor & $46.95 \mu \mathrm{M}$ & $5.22 \mu \mathrm{M}$ \\
\hline XIAP Inhibitor & $51.08 \mu \mathrm{M}$ & $9.71 \mu \mathrm{M}$ \\
\hline
\end{tabular}

C b
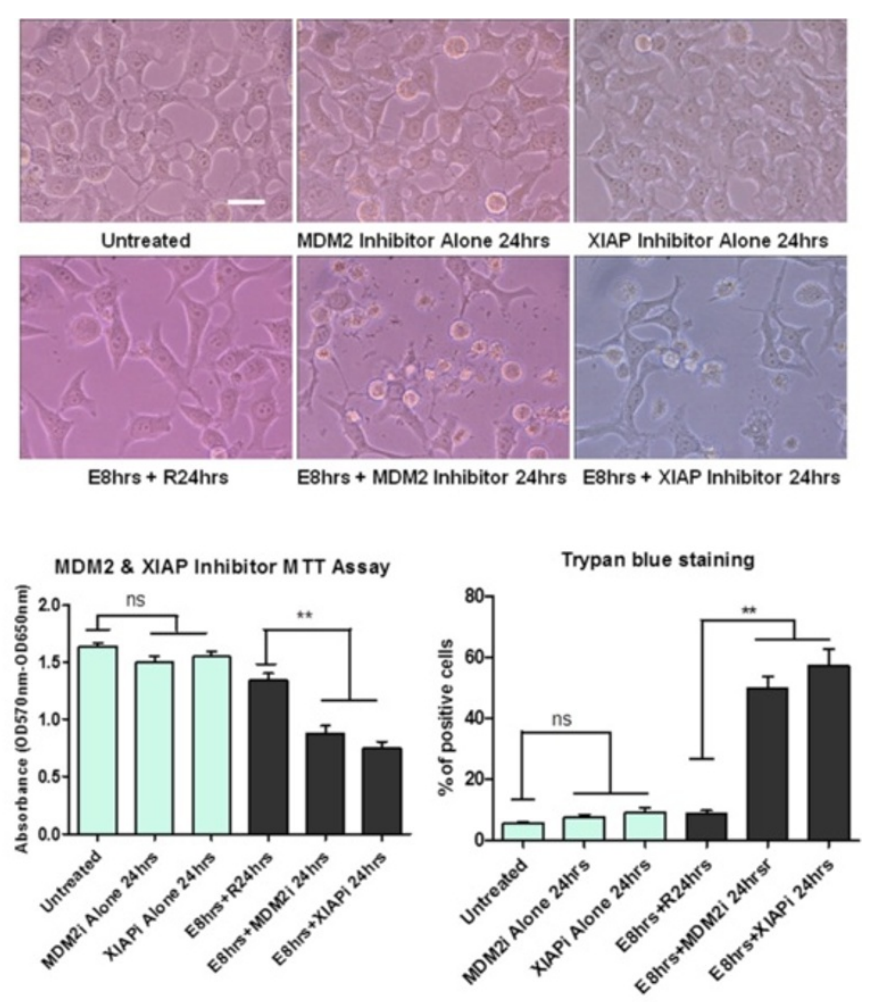

d

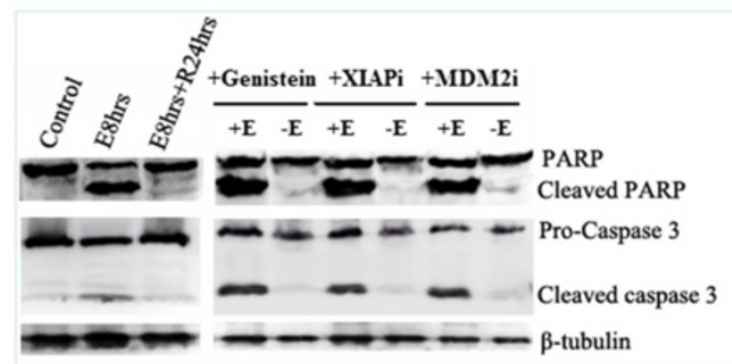

e

Hoechst 33342

Alexa 488

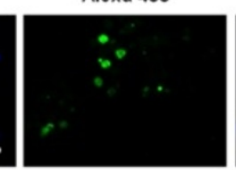

Merged
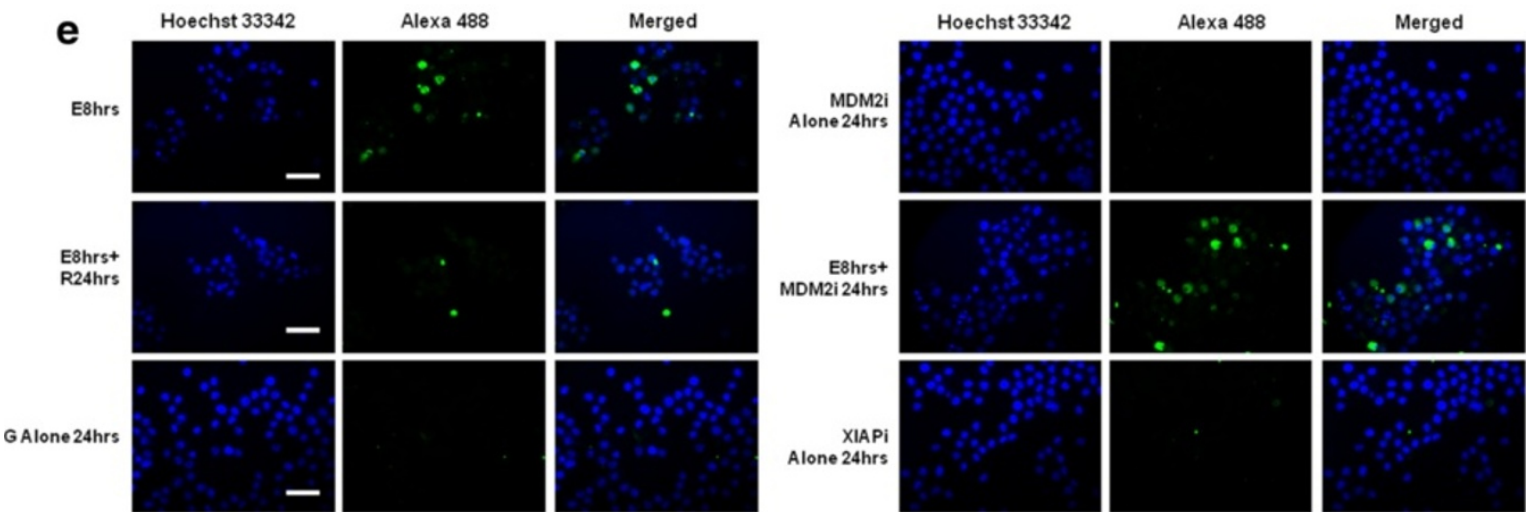

Einrst
MDM2i 24 hrs
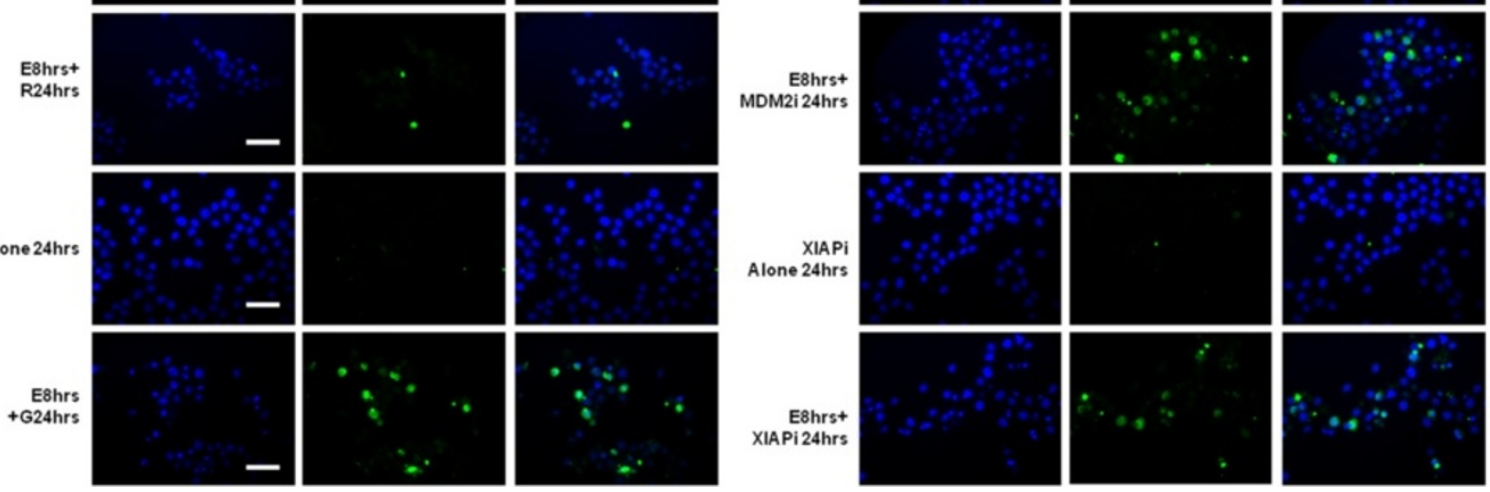

Figure 4 (See legend on next page.) 
(See figure on previous page.)

Figure 4 MDM2 and XIAP inhibitor potentiated the cell death and caused persistent caspase activity in stressed HeLa cell.

(a). Dose-dependent responsive curves of MDM2 inhibitor (Boranyl-chalcone) and XIAP inhibitor (Embelin) on unstressed cells (Inhibitor Alone) and stressed cells (E8 hrs + Inhibitor) of HeLa for $48 \mathrm{~h}$ treatment by MTT assay. Two-way ANOVA was used to test the significance of ethanol stress as the source of variance. IC50 of each group is summarized in table. (b). Morphology of HeLa cells recovered $24 \mathrm{~h}$ from stress (E8 hrs + R24 hrs) and cells treated with MDM2 inhibitor $(10 \mu \mathrm{M})$ or XIAP inhibitor $(20 \mu \mathrm{M})$ for $24 \mathrm{~h}$ during recovery period (E8hrs + inhibitor 24 hrs). Inhibitor treatment

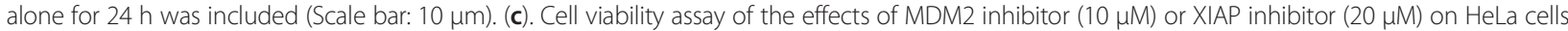
undergoing recovery from stress treatment for $24 \mathrm{~h}$ treatment. Left: MTT cell viability assay; Right: Trypan blue dye exclusion assay (Mean \pm SEM, $\mathrm{n}=3$; $\mathrm{ns}$ indicates: no significance; ** indicates: $p<0.01$ ). XIAPi stands for XIAP inhibitor; MDM2i stands for MDM2 inhibitor. (d) Western blot analysis of the effects of genistein $(15 \mu \mathrm{g} / \mathrm{ml})$, MDM2 inhibitor $(10 \mu \mathrm{M})$ and XIAP inhibitor $(20 \mu \mathrm{M}) 24 \mathrm{~h}$ treatment on HeLa cells undergoing stress recovery. +E: 5.5\% ethanol stress for 8 hrs followed by genistein and inhibitor treatment. -E: without ethanol stress treatment. (e). Immunostaining of cleaved caspase- 3 of stressed and unstressed HeLa cells treated with genistein $(15 \mu \mathrm{g} / \mathrm{ml})$, MDM2 inhibitor $(10 \mu \mathrm{M})$ and XIAP inhibitor (20 $\mu \mathrm{M})$. Cleaved caspase-3 (Green) stained with Alexa Fluor ${ }^{\oplus}$ 488-conjugated antibody, Nuclei (Blue) stained with Hoechst 33342 (Scale bar: $100 \mu \mathrm{m}$ ).

evidence that ethanol-stressed HeLa cells displayed features including cell shrinkage, nucleus condensation, PS externalization, mitochondrial disruption and dysfunction, and caspase activation (Figure 1 and Figure 2e), which are characterized of apoptotic cell death [28-30].
Overall, the result that stressed HeLa cells showing apoptotic features could recover after stress removal is consistent with previous studies that loss of membrane asymmetry in early apoptosis [31,32] and the activation of caspase activity $[33,34]$ by different apoptotic inducer

a

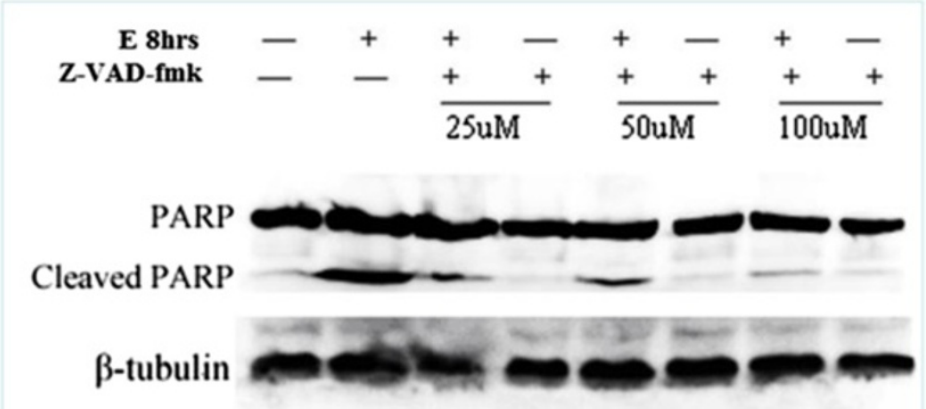

b

Caspase Inhibitor/Genistein MTT Assay

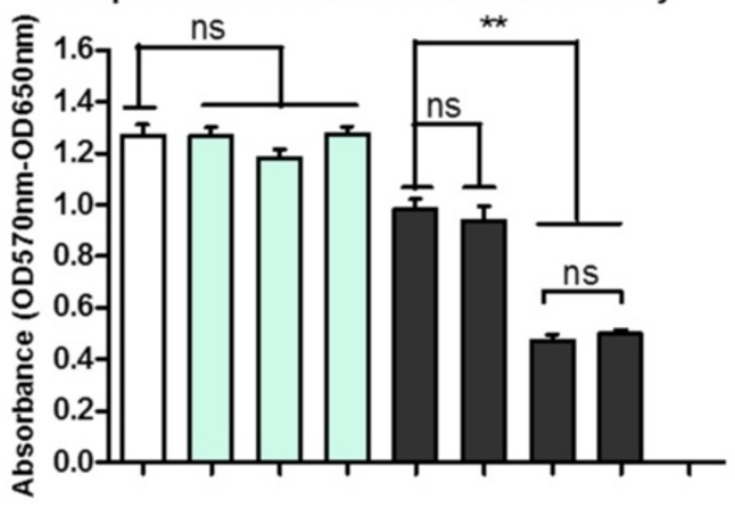

E 8rs $-\quad-\quad-++++$

Washing $-+-\infty++++$

Genistein (15 ug/ml) - $-+-c_{-}+$

Z-VAD-fmk (100 uM) - - + - + +

Figure $\mathbf{5}$ Caspase activity inhibition did not rescue the effects of genistein's effect on recovering HeLa cells. (a). HeLa cells were stressed or unstressed with 5.5\% ethanol for $8 \mathrm{~h}$ (E8 hrs), in the absence (-) or the presence (+) of 25, 50, and $100 \mu \mathrm{M}$ of general caspase inhibitor Z-VAD -fmk, and the PARP cleavage was examined by Western blot. (b). MTT assay about genistein's effects on stressed HeLa cell, in the absence (-) or the presence $(+)$ of general caspase inhibitor Z-VAD-fmk $(100 \mu \mathrm{M})$ for $24 \mathrm{~h}$. E 8 hrs stands for $8 \mathrm{~h}$ ethanol stress; Washing stands for the removal of ethanol-containing medium (Data expressed as Mean $\pm \mathrm{SEM}, \mathrm{n}=3$; ns indicates: no significance; ${ }^{* *}$ indicates: $p<0.01$ ). 


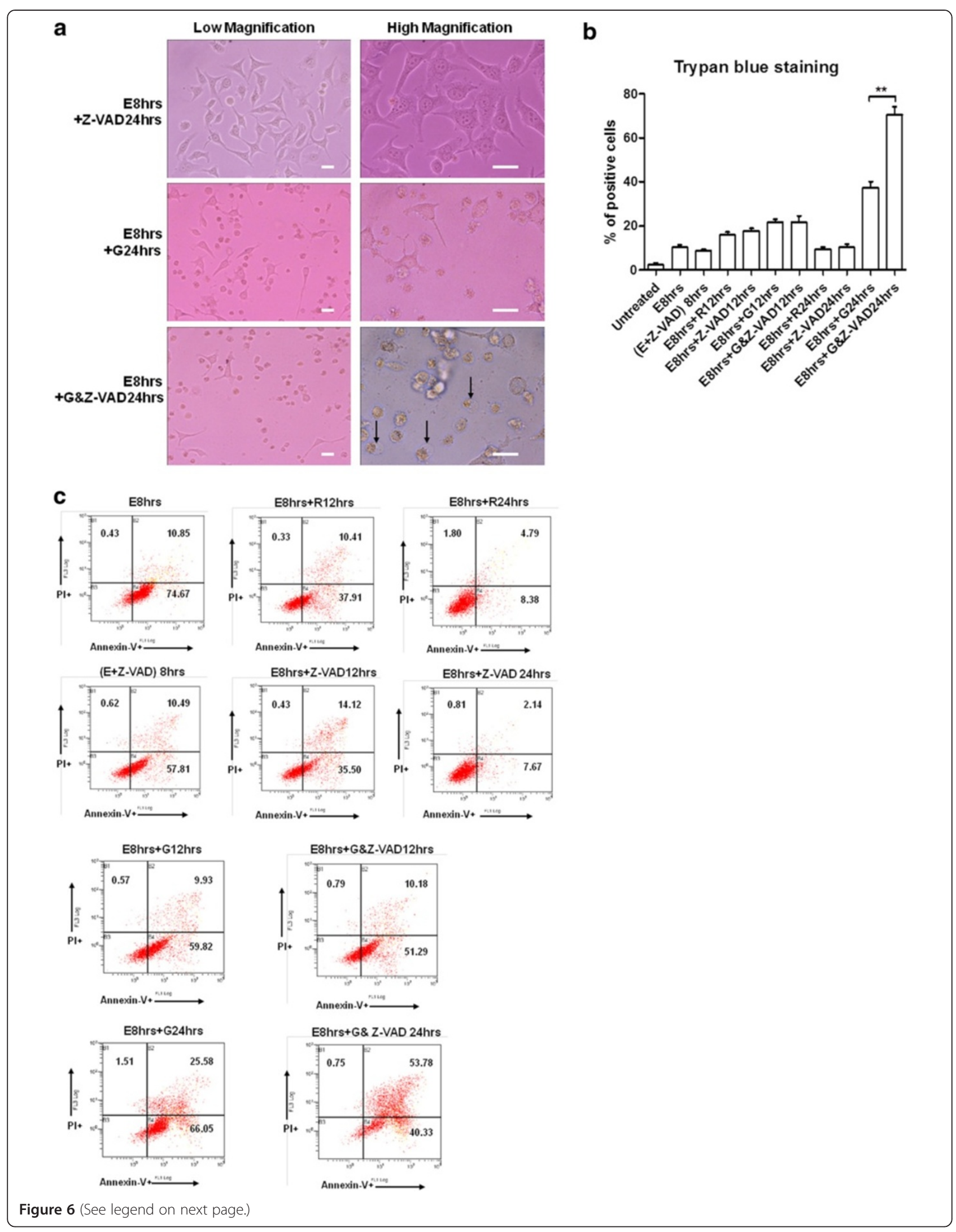


(See figure on previous page.)

Figure 6 Caspase activity inhibition shifted the effects of genistein to secondary necrosis. (a). Morphology of HeLa cells undergoing the recovery from stress treatment, in the presence of $100 \mu \mathrm{M}$ Z-VAD-fmk (upper), or $15 \mu \mathrm{g} / \mathrm{ml}$ genistein (middle), or both (bottom) for $24 \mathrm{~h}$. Arrows indicate the cell swelling and membrane rupture of shrunk cells. (b). Trypan blue dye exclusion assay of HeLa cells after the removal of stress, in the presence of $15 \mu \mathrm{g} / \mathrm{ml}$ genistein or $100 \mu \mathrm{M} Z$ Z-VAD-fmk or both for $12 \mathrm{~h}$ and $24 \mathrm{~h}$ respectively (Data expressed as Mean $\pm S E M, n=3$;

** indicates: $p<0.01)$. (c). Annexin $V$ and propidium iodide staining assay of HeLa cells after stress treatment and stress removal in the presence of $15 \mu \mathrm{g} / \mathrm{ml}$ genistein or $100 \mu \mathrm{M}$ Z-VAD-fmk or both for $12 \mathrm{~h}$ and $24 \mathrm{~h}$ respectively. (E + Z-VAD) 8 hrs stands for ethanol stress for $8 \mathrm{~h}$ in the presence of Z-VAD. The percentage of events early apoptotic (lower right), and late apoptotic or necrotic (upper right) were indicated in each diagram. were reversible. Reversible apoptotic event was also well characterized by time-lapse video microscopy in previous study, which showed that apoptotic dying cancer cells regained normal morphology and proliferate after the removal of inducer [34]. The reversibility of cancer cell from apoptosis raised interesting question whether apoptotic recovery contributes to survival or repopulation of cancer after cycles of chemotherapy.

Accumulating evidence suggested that cancer preventative agents might be combined with chemotherapy or radiotherapy to enhance treatment outcome [23]. Soybean isoflavone genistein is the one of the most widely studied compound for its prominent anti-proliferation effects on cancer cells $[16,17]$. In addition to its cytotoxicity and anti-proliferation effect, we showed that genistein could promote cell death of ethanol-stressed HeLa cells with apoptotic features (Figure 2). As genistein was reported to enhance the effects of anti-cancer drugs $[16,17,21,22]$ and anti-cancer agents could induce apoptosis in cancer cells [3-5], the death-promoting effect of genistein on stressed HeLa cells may at least partially contribute to enhanced anti-tumor effect when it was combined with anti-cancer drugs.

Our results also demonstrated that the recovering HeLa cells were addicted to transcription and translation processes (Figure 3a), implying that cells undergoing recovery process were highly dependent on de novo synthesis. As the cleavage of cellular proteins by activated caspase is irreversible, it is anticipated that caspase activity should be counteracted and the damaged cellular proteins should be replenished if a cell is capable of recovering from caspase-dependent apoptotic event [35]. In this view, de novo synthesis may not only function to compensate for cellular damages, but also to clear the caspase activity. Our data showed the up-regulation of XIAP and MDM2 genes after the stress removal in HeLa cell (Figure $3 \mathrm{c}$ ). XIAP protein is a member of IAP (Inhibitors of Apoptosis Proteins) family, which not only directly interacts with activated caspases to block their activities but also functions as E3 ubiquitin ligase to assist the ubiquitination of activated caspases and their subsequent degradation [36,37]. MDM2 is a well-documented ubiquitin ligase binding to p53 to negatively regulate its stability and transcriptional activity [38,39]. The up-regulation of $X I A P$ and $M D M 2$ may function to eliminate the caspase activity and terminate the p53-dependent apoptosis signal after stress removal. Indeed, inhibiting MDM2 or XIAP activity caused persistent caspase activity and enhanced cell death (Figure 4). In addition, CREB1 gene that acts as a transcription factor for other pro-survival genes [40,41] was up-regulated during recovery phase (Figure 3c). Together, our data supports the hypothesis that both counter-apoptotic signals and pro-survivor signals are involved in the recovery process from ethanol-induced apoptotic events.

Genistein exerted obvious interference on the expression profiles of ATF3, XIAP, MDM2, TP53, NOXA and PUMA genes in HeLa cell (Figure 3c). ATF3 gene encodes a rapidly-induced stress sensor that functions to stabilize p53 protein and contribute to the acceleration of pro-apoptotic signal $[42,43]$. Our data showed that genistein treatment delayed the down-regulation of ATF3 after the removal of stress (Figure 3c). Together with attenuated MDM2 expression level, delayed down-regulation of ATF by genistein may function to increase p53 level and the subsequent trans-activation of p53 target genes NOXA and PUMA (Figure 3c), which encode the pro-apoptotic proteins Noxa and Puma $[44,45]$. Interestingly, genistein also delayed the down-regulation of anti-apoptotic gene MCL1 (Figure 3c; ref. [46]). However, this anti-apoptotic signal may be rapidly overwhelmed by the up-regulation of NOXA and PUMA genes.

Now that anti-apoptotic genes XIAP and MDM2 were up-regulated during the recovery phase and genistein suppressed their up-regulation (Figure 3c), and XIAP or MDM2 inhibitor caused persistent caspase activity in the recovering cells (Figure $4 \mathrm{~d}$, e), the death-enhancing effects of genistein may result from the hindrance to the termination of apoptotic effectors. However, the addition of caspase inhibitor did not rescue the cells from genistein's inhibitory effects (Figure 5). Genistein together with caspase inhibitor increased the percentage of necrotic events in the cells recovering from apoptosis (Figure 6). Previous studies have demonstrated that genistein could suppress the AKT and NF- $\mathrm{kB}$ pro-survivor signaling pathway in various type of cancer cells [21,47-49]. AKT- 
NF- $\mathrm{kB}$ pro-survivor signaling pathway was reported to up-regulate anti-apoptotic genes like XIAP [50,51]. AKT also functioned to activate and enhance MDM2 activity $[52,53]$. Indeed, previous researchers have showed that genistein down-regulated MDM2 at transcriptional and post-translational level [54] and reduced XIAP protein was detected following genistein treatment [55]. In this view genistein's death-promoting action on the cellular recovery may result from both the persistent pro-apoptotic signal and the impaired recovering processes due to the impairment of pro-survival pathway in HeLa cell. However, it remains to be clarified how the recovering cells diverted the effect of genistein to necrotic death in the presence of caspase inhibitor.

Collectively, on the basis of our results and previous studies, we propose a hypothetic pathway through which genistein may exert its death-promoting effect on the stressed HeLa cells (Figure 7). Possibly through inhibiting the activity of AKT and NF- $\mathrm{kB}$, genistein suppresses the up-regulation of XIAP and MDM2 that were showed to be involved in the recovery process. Genistein treatment also sustains ATF3 expression level after the removal of stress, which together with decreased $M D M 2$ level contributes to the stabilization of p53. p53 accumulation trans-activates its target genes including NOXA and PUMA to cause persistent pro-apoptotic signals. Since AKT pathway functions to promote protein synthesis, regulate glucose metabolism, suppress pro-apoptotic signal and activate NF-кB $[56,57]$, the attenuated AKT and NF-кB activity due to genistein treatment may weaken the ability to antagonize existing apoptotic effectors and impair the recovery from the damages insulted by the stress.

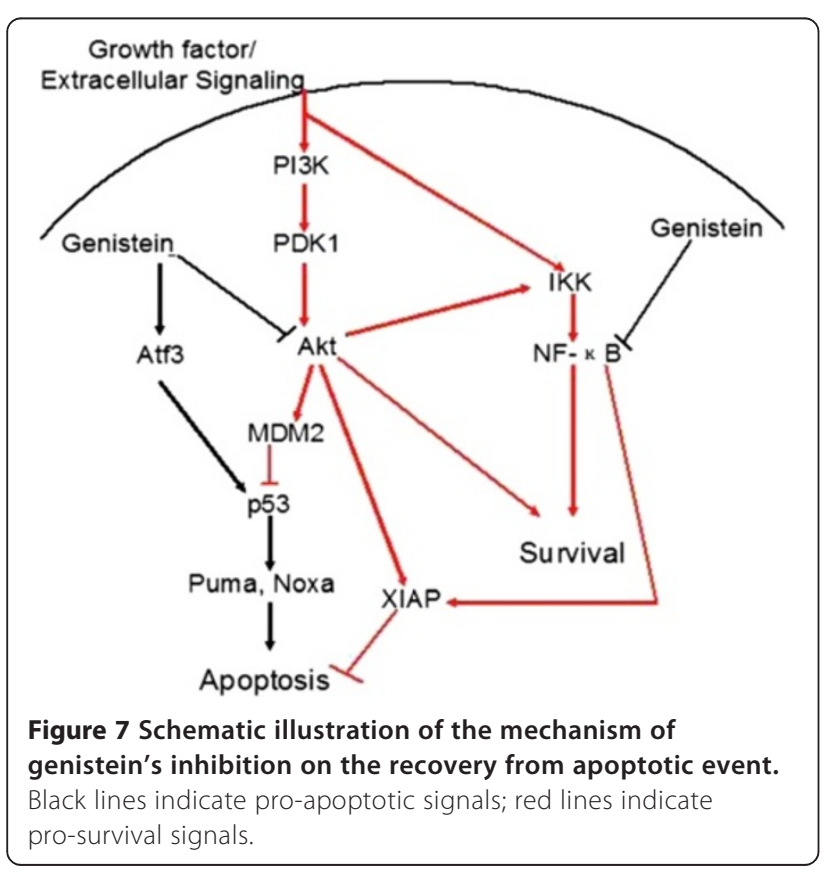

\section{Conclusions}

In summary, this study revealed novel effects of genistein on inhibiting the recovery of HeLa cells from apoptotic events. This effect of genistein on other types of cancer cells and related mechanisms remain to be elucidated, and it is possible that this effect could account for the enhanced anti-tumor effect when genistein is combined with chemotherapeutic drugs. It is anticipated that the discovery of more effective inhibitor of apoptotic recovery could help to improve chemotherapy.

\section{Methods}

\section{Cell lines and cell culture}

Human cervical cancer cells HeLa (from ATCC) was cultured in DMEM (Dulbecco's minimum essential medium, Gibco). The medium was supplemented with $10 \%$ fetal bovine serum (Hyclone, Thermo Scientific), $100 \mathrm{U} / \mathrm{ml}$ penicillin and $100 \mu \mathrm{g} / \mathrm{ml}$ streptomycin (Gibco, Carlsbad, CA, USA) at $37^{\circ} \mathrm{C}$ under humidified atmosphere of $5 \% \mathrm{CO} 2 / 95 \%$ air. Cells were seeded on tissue culture plates until cell density reached $60 \%$ to $70 \%$ confluence before being subjected to each experiment. The compounds used for testing the death-promoting effect on stressed cancer cell includes: Genistein (Cayman Chemical, Ann Arbor, MI, USA), XIAP inhibitor Embelin (Sigma-Aldrich, St. Louis, MO, USA), MDM2 inhibitor boranyl-chalcone (Calbiochem, La Jolla, CA, USA), General caspase inhibitor Z-VAD-fmk (MP Biochemical, Aurora, Ohio, USA), Actinomycin D and Cycloheximide (Sigma-Aldrich).

\section{Live cell staining and imaging}

Cells were seeded on a glass coverslip (Marienfeld, Lauda-Ku"nigahofen, Germany) in dish (Nunc, $60 \mathrm{~mm}$ ). Mitochondria was stained with $50 \mathrm{nM}$ MitoTracker Red CMXRos (Invitrogen, Eugene, Oregon, USA) for 45 minutes and nuclei were stained with $250 \mathrm{ng} / \mathrm{ml}$ Hoechst 33342 (Invitrogen) for 15 minutes. Then the cells were washed three times with PBS and then cultured in $\mathrm{CO}_{2}$ independent medium (Invitrogen) on a thermo-cell culture FCS2 chamber (Bioptechs, Butler, PA,USA) that was mounted onto adapter in the stage of an inverted fluorescence microscope Cell Observer (Carl Zeiss, Jena, Germany). Cell morphology was visualized by differential interference contrast (DIC) channel. Mitochondria and nucleuses were detected by fluorescence excited at 561 and $405 \mathrm{~nm}$ respectively. Cell images were captured with a monochromatic CoolSNAP FX camera (Roper Scientific, Pleasanton, CA, USA) with x63 numerical aperture (NA) 1.4 Plan-Apochromat objective (Carl Zeiss), and analyzed by AxioVision 4.2 software (Carl Zeiss).

\section{MTT cell viability assay}

Cells were seed for $24 \mathrm{~h}$ on flat bottomed plates (Nunc, 96 well). After different treatments, $16 \mu \mathrm{L}$ of 
3-(4,5-dimethylthiazol-2-yl)-2,5 -diphenyltetrazolium bromide (MTT) reagent ( $5 \mathrm{mg} / \mathrm{ml}$, Sigma-Aldrich) was added to each well and incubated at $37^{\circ} \mathrm{C}$ for $3 \mathrm{~h}$. After incubation, culturing medium was aspirated and $120 \mu \mathrm{l}$ DMSO (Sigma-Aldrich) was added to each well for 10 minutes' incubation at room temperature. Absorbance was measured at a wavelength of $570 \mathrm{~nm}$ (reference wavelength $650 \mathrm{~nm}$ ) by SpectraMax 250 microplate reader (Molecular Devices Corp, Concord, ON, Canada).

\section{BrdU cell proliferation assay}

The cell proliferation ELISA, BrdU kit (Roche) was used according to the manufacturer's instructions. Cells were seeded into 96-well plates $\left(5 \times 10^{3}\right.$ cells / well $)$ and treatments were added the next day. After each treatment, cells were labeled with a $10 \mathrm{mM}$ BrdU solution (5'bromo-2' deoxyuridine) in culture medium and incubated for an additional $48 \mathrm{~h}$ at $37^{\circ} \mathrm{C}$. The medium was then replaced with $100 \mathrm{ul}$ Fixative/Denaturing solution and incubate for 30 minutes at room temperature. Anti-BrdU Antibody in 1:1000 dilutions was added to each well and the plates were incubated at room temperature for $1 \mathrm{~h}$. After three washing steps, peroxidase-substrate color development solution $(100 \mu \mathrm{l})$ was added to each well and the color reaction was stopped after 10 minutes with $25 \mu \mathrm{l} 1 \mathrm{M}$ $\mathrm{H}_{2} \mathrm{SO}_{4}$. Absorbance of samples was measured at $370 \mathrm{~nm}$ (reference wavelength $492 \mathrm{~nm}$ ).

\section{LDH Cytotoxicity Assay}

The cell death LDH cytotoxicity detection kit (Roche) was used according to the manufacturer's instructions Briefly, cells $\left(1 \times 10^{4} /\right.$ well $)$ were seeded in 96-well plates in $100 \mu \mathrm{l}$ of medium and incubated at $37^{\circ} \mathrm{C}$ for $24 \mathrm{~h}$ before treatment. The maximum LDH release (high control) from cells was determined by the addition of $2 \% 100 \mathrm{ul}$ Triton X-100 (Sigma-Aldrich), followed by incubation at $37^{\circ} \mathrm{C}$ for $1 \mathrm{~h}$. The minimum LDH release was determined from untreated cells. After centrifugation at $200 \mathrm{~g}$, supernatants of samples with different treatments were transferred to a new 96-well plate, and the reaction mixture from the kit was added. After incubate for 30 minutes at room temperature, absorbance at $490 \mathrm{~nm}$ (reference wavelength $620 \mathrm{~nm}$ ) was recorded using microplate reader. ABS (absorbance) experiment $=($ mean absorbance from the treated cells $)$ - (absorbance from blanks); ABS low $=($ mean absorbance from low control, untreated cells) - (absorbance from blanks); $\mathrm{ABS}$ high = (mean absorbance from high control, Triton X-100 treated cells) - (absorbance from blanks); the percentage of cytotoxicity was calculated as: (Abs experiment - Abs low)/(Abs high - Abs low).

\section{Quantitative Real-Time PCR}

RNA was extracted using the RNeasy Mini Kit (Qiagen) according to the manufacturer's protocol. RNA concentrations were measured spectrophotometrically. First-strand cDNA was synthesized from $0.1 \mu \mathrm{g}$ RNA template using Reverse Transcriptase Polymerase Chain Reaction. RT-qPCR amplifications were conducted on BioRad iQ 5 Multicolor Real-time PCR Detection System (Biorad), using SYBR ${ }^{\circ}$ Green qPCR Supermix (Invitrogen). Triplicate reactions were performed for each sample, both for target and reference gene. The expression level of each gene was determined by absolute quantification method. First, the absolute value of each gene was determined by standard curve. In each sample, the value of each target gene was divided by the value of GAPDH reference gene for normalization. The normalized data were expressed as normalized mRNA level (the ratio of target gene level to reference gene level). The Primers used for RT-qPCR are listed in Table 1.

\section{Western blot}

Proteins collected from cell lysate were separated on a 10-15\% SDS-PAGE gel and then transferred onto the Immun-Blot PVDF membrane (Biorad) using semi-dry transfer system (Biorad). After blocking, membrane was incubated overnight at $4{ }^{\circ} \mathrm{C}$ with 1:1000 primary antibodies (anti-caspase 3, anti-PARP antibody from Cell Signaling, Beverly, MA USA; anti-caspase 7, anti-caspase 9 and

Table 1 Primer sequences for target genes

\begin{tabular}{|c|c|c|}
\hline \multirow[t]{2}{*}{ Gene symbol } & Forward Primer ( $5^{\prime}$ to $\left.3^{\prime}\right)$ & \multirow[t]{2}{*}{ Product size } \\
\hline & Reverse Primer $\left(5^{\prime}\right.$ to $3^{\prime} \mathrm{c}$ & \\
\hline \multirow[t]{2}{*}{$B C L 2$} & ATGTCCAGCCAGCTGCACCTGAC & $319 \mathrm{bp}$ \\
\hline & $\overline{\text { GCAGAGTCTTCAGAGACAGCCAGG }}$ & \\
\hline \multirow[t]{2}{*}{ MDM2 } & CCCTGGTTAGACCAAAGCCAT & $190 \mathrm{bp}$ \\
\hline & GGCACGCCAAACAAATCTCC & \\
\hline \multirow[t]{2}{*}{ GAPDH } & CATGAGAAGTATGACAACAGCCT & $113 \mathrm{bp}$ \\
\hline & AGTCCTTCCACGATACCAAAGT & \\
\hline \multirow[t]{2}{*}{ XIAP } & GGGTTCAGTTTCAAGGACATTAAG & $182 \mathrm{bp}$ \\
\hline & CGCCTTAGCTGCTCTTCAGTAC & \\
\hline \multirow[t]{2}{*}{ ATF3 } & AACCTGACGCCCTITGTCAAG & $138 \mathrm{bp}$ \\
\hline & TACCTCGGCTITTGTGATGGA & \\
\hline \multirow[t]{2}{*}{$B A X$} & GATGCGTCCACCAAGAAGCT & $170 \mathrm{bp}$ \\
\hline & CGGCCCCAGTTGAAGTTG & \\
\hline \multirow[t]{2}{*}{ MCL1 } & TAAGGACAAAACGGGACTGG & $137 \mathrm{bp}$ \\
\hline & ACCAGCTCCTACTCCAGCAA & \\
\hline \multirow[t]{2}{*}{ TP53 } & GAGGTTGGCTCTGACTGTACC & $133 \mathrm{bp}$ \\
\hline & TCCGTCCCAGTAGATTACCAC & \\
\hline \multirow[t]{2}{*}{ CREB1 } & TTAACCATGACCAATGCAGCA & $140 \mathrm{bp}$ \\
\hline & TGGTATGTTTGTACGTCTCCAGA & \\
\hline \multirow[t]{2}{*}{ PUMA } & GACCTCAACGCACAGTACGAG & $98 \mathrm{bp}$ \\
\hline & AGGAGTCCCATGATGAGATTGT & \\
\hline \multirow[t]{2}{*}{ NOXA } & ATGCCTGGGAAGAAGGCGC & $164 \mathrm{bp}$ \\
\hline & CAGGTTCCTGAGCAGAAGAGT & \\
\hline
\end{tabular}


anti- $\beta$-tubulin antibody from Santa Cruz Biotechnology, CA, USA). After washing three times with TBST, the membrane was incubated in corresponding horseradish peroxidase- conjugated secondary antibody (Bio-Rad, Hercules, CA, USA) at 1:5000 dilution for another $1 \mathrm{~h}$. The excessive antibody was washed away three times with TBST and signal was developed with ECL western blotting detection system (Amersham Biosciences).

\section{Annexin V/ Propidium lodide Assay}

After each treatment, cells were collected by trypsinization and washed with chilled PBS. The cells were stained with

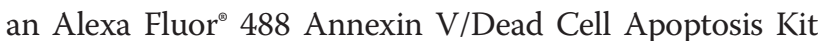
(Invitrogen, Eugene, Oregon, USA) according to manufacturer's instruction. Briefly, cell density was determined and $1 \times 10^{6}$ cells were suspended in $1 \mathrm{ml} 1 \times$ annexin binding buffer, followed by addition with 10 ul Alexa Fluor 488 Annexin V (component A) and $2 \mathrm{ul} 100 \mu \mathrm{g} / \mathrm{ml}$ propidium iodide (component B) in the dark, at room temperature for 5 minutes, and immediately analyzed by flow cytometry (Cytomics FC500, Beckman Coulter, CA, USA). Cells Annexin V-positive/ PI-negative were considered as early apoptotic, cells doubly positive as late apoptotic or necrotic.

\section{Trypan Blue Dye Exclusion Assay}

Cells were washed with PBS twice and detached using $0.25 \%$ /EDTA Trypsin (Gibco). Cells were collected by centrifuge at $200 \mathrm{~g}$ for 5 minutes and the supernatant was discarded. The pellet was re-suspended in $1 \mathrm{ml}$ PBS, and 1 part of $0.4 \%$ trypan blue (Gibco) was mixed with 1 part cell suspension. 10ul trypan blue/cell mixture was added to hemacytometer (Hausser Scientific, Horsham, PA, USA) for quantification. The unstained (viable) and stained (nonviable) cells were counted separately.

\section{Cleaved-Caspase 3 Immunostaining}

Cells $\left(1 \times 10^{6} / \mathrm{mL}\right)$ were collected and fixed in $4 \%$ paraformaldehyde (Sigma-Aldrich) for 10 minutes at $37^{\circ} \mathrm{C}$, following by permeabilization with $0.1 \%$ (v/v in fixative) Triton X-100 (Sigma-Aldrich) for 30 minutes at room temperature. After three times' rinse with incubation buffer (0.5\% BSA in PBS) by centrifuge, cells were incubated with 1:1600 rabbit anti-cleaved caspase-3 IgG (Cell Signaling, Beverly, MA) overnight at $4^{\circ} \mathrm{C}$. After rinsing three times, cells were incubated with 1:1000 Alexa Fluor ${ }^{\circ} 488$-conjugated goat anti-rabbit IgG (Invitrogen, Eugene, Oregon, USA) solution with $250 \mathrm{ng} / \mathrm{ml}$ Hoechst 33342 (Invitrogen) for $1 \mathrm{~h}$ at room temperature. Then cells were rinsed with incubation buffer and collected by centrifuge. Cell pellet was re-suspended in $0.1 \mathrm{ml}$ Anti-fade Buffer (Invitrogen). $0.01 \mathrm{ml}$ of suspended cells was spread onto slides for fluorescence microscopy analysis.

\section{Statistical analysis}

Each experiment was repeated three times for consistency of the result. The results were either expressed relative to controls, or as percentages of the cell population (mean \pm $\mathrm{SE}, \mathrm{n}=3$ ). IC50 value was calculated using GraphPad Prism 5 software. Significance of the differences in multiple mean values comparison was determined by one-way ANOVA when there is only one variable. Twoway ANOVA was used when there were two variables and $P<0.05$ was considered to be statistically significant.

\section{Abbreviations}

AKT: also known as Protein Kinase B (PKB); ATF3: Activating Transcription

Factor 3; CREB1: CAMP Responsive Element Binding protein 1; MDM2: Murine Double Minute; NF-kB: Nuclear Factor kappa-light-chain-enhancer of activated B cells; PARP: Poly (ADP-ribose) Polymerase; PS: Phosphatidylserine; XIAP: X-linked Inhibitor of Apoptosis Protein.

\section{Competing interests}

The authors declare that they have no competing interests.

\section{Author's contributions}

Conceived and designed the experiments: XX, MCF. Performed the experiments: XX, SSW; Analyzed the data: XX, SSW; Contributed reagents/ materials/analysis tools: XX, SSW; Wrote the paper: XX, SSW, CSW; All authors read and approved the final manuscript.

\section{Acknowledgements}

This work described in this paper was supported by the funding from the University Grants Committee of the Hong Kong Special Administrative Region, China (Project No. AoE/B-07/99), Lee Lysan Foundation, and Lo Kwee-Seong Biomedical Research Endowment Fund.

Received: 28 February 2013 Accepted: 21 June 2013

Published: 26 June 2013

\section{References}

1. Chabner BA, Roberts TG: Timeline: chemotherapy and the war on cancer. Nat Rev Cancer 2005, 5(1):65-72.

2. Kasibhatla S, Tseng B: Why target apoptosis in cancer treatment? Mol Cancer Ther 2003, 2(6):573-580.

3. Johnstone RW, Ruefli AA, Lowe SW: Apoptosis: a link between cancer genetics and chemotherapy. Cell 2002, 108(2):153-164.

4. Dive C, Hickman JA: Drug-target interactions: only the first step in the commitment to a programmed cell death? Br J Cancer 1991, 64(1):192-196

5. Schmitt CA, Lowe SW: Apoptosis and therapy. J Pathol 1999, 187(1):127-137.

6. Hanahan D, Weinberg RA: The hallmarks of cancer. Cell 2000, 100(1):57-70.

7. Gerl R, Vaux DL: Apoptosis in the development and treatment of cancer. Carcinogenesis 2005, 26(2):263-270.

8. Lowe SW, Lin AW: Apoptosis in cancer. Carcinogenesis 2000, 21(3):485-495.

9. Letai AG: Diagnosing and exploiting cancer's addiction to blocks in apoptosis. Nat Rev Cancer 2008, 8(2):121-132.

10. Kurahashi $N$, Iwasaki M, Inoue M, Sasazuki S, Tsugane S: Plasma isoflavones and subsequent risk of prostate cancer in a nested case-control study: the Japan Public Health Center. J Clin Oncol 2008, 26(36):5923-5929.

11. Shon YH, Park SD, Nam KS: Effective chemopreventive activity of genistein against human breast cancer cells. J Biochem Mol Biol 2006, 39(4):448-451.

12. Taylor CK, Levy RM, Elliott JC, Burnett BP: The effect of genistein aglycone on cancer and cancer risk: a review of in vitro, preclinical, and clinical studies. Nutr Rev 2009, 67(7):398-415.

13. Li Y, Upadhyay S, Bhuiyan M, Sarkar FH: Induction of apoptosis in breast cancer cells MDA-MB-231 by genistein. Oncogene 1999, 18(20):3166-3172.

14. Barnes S: Effect of genistein on in vitro and in vivo models of cancer. J Nutr 1995, 125(3 Suppl):777S-783S. 
15. Hwang JT, Ha J, Park OJ: Combination of 5-fluorouracil and genistein induces apoptosis synergistically in chemo-resistant cancer cells through the modulation of AMPK and COX-2 signaling pathways. Biochem Biophys Res Commun 2005, 332(2):433-440.

16. Shen J, Tai YC, Zhou J, Stephen Wong CH, Cheang PT, Fred Wong WS, Xie Z, Khan M, Han JH, Chen CS: Synergistic antileukemia effect of genistein and chemotherapy in mouse xenograft model and potential mechanism through MAPK signaling. Exp Hematol 2007, 35(1):75-83.

17. Kim SH, Kim SH, Kim YB, Jeon YT, Lee SC, Song YS: Genistein Inhibits Cell Growth by Modulating Various Mitogen-Activated Protein Kinases and AKT in Cervical Cancer Cells. Ann Ny Acad Sci 2009, 1171:495-500.

18. Sasamura H, Takahashi A, Yuan J, Kitamura H, Masumori N, Miyao N, Itoh N, Tsukamoto T: Antiproliferative and antiangiogenic activities of genistein in human renal cell carcinoma. Urology 2004, 64(2):389-393.

19. Sarkar FH: Molecular evidence for increased antitumor activity of gemcitabine by genistein in vitro and in vivo using an orthotopic model of pancreatic cancer. Cancer Res 2005, 65(19):9064-9072.

20. Suvarna B, Debashis S, Robert T, David LD, James DB: Gene Expression Changes Induced by Genistein in the Prostate Cancer Cell Line LNCaP. Open Prost Cancer J 2010, 3:86-98.

21. Li Y, Ahmed F, Ali S, Philip PA, Kucuk O, Sarkar FH: Inactivation of nuclear factor kappaB by soy isoflavone genistein contributes to increased apoptosis induced by chemotherapeutic agents in human cancer cells. Cancer Res 2005, 65(15):6934-6942.

22. Banerjee S, Zhang Y, Ali S, Bhuiyan M, Wang Z, Chiao PJ, Philip PA Abbruzzese J, Sarkar FH: Molecular evidence for increased antitumor activity of gemcitabine by genistein in vitro and in vivo using an orthotopic model of pancreatic cancer. Cancer Res 2005, 65(19):9064-9072.

23. Sarkar FH, Li YW: Using chemopreventive agents to enhance the efficacy of cancer therapy. Cancer Res 2006, 66(7):3347-3350.

24. Castaneda F, Rosin-Steiner S: Low concentration of ethanol induce apoptosis in HepG2 cells: role of various signal transduction pathways. Int J Med Sci 2006, 3(4):160-167

25. Zhou Z, Sun X, Kang YJ: Ethanol-induced apoptosis in mouse liver: Fas- and cytochrome c-mediated caspase-3 activation pathway. Am J Pathol 2001, 159(1):329-338.

26. Asai K, Buurman WA, Reutelingsperger CP, Schutte B, Kaminishi M: Low concentrations of ethanol induce apoptosis in human intestinal cells. Scand J Gastroenterol 2003, 38(11):1154-1161.

27. Wu D, Cederbaum Al: Ethanol-induced apoptosis to stable HepG2 cell lines expressing human cytochrome P-4502E1. Alcohol Clin Exp Res 1999 23(1):67-76.

28. Taylor RC, Cullen SP, Martin SJ: Apoptosis: controlled demolition at the cellular level. Nat Rev Mol Cell Bio 2008, 9(3):231-241.

29. Kroemer G, Galluzzi L, Vandenabeele P, Abrams J, Alnemri ES, Baehrecke EH, Blagosklonny MV, El-Deiry WS, Golstein P, Green DR, et al: Classification of cell death: recommendations of the Nomenclature Committee on Cell Death 2009. Cell Death Differ 2009, 16(1):3-11.

30. Galluzzi L, Vitale I, Abrams JM, Alnemri ES, Baehrecke EH, Blagosklonny MV, Dawson TM, Dawson VL, El-Deiry WS, Fulda S: Molecular definitions of cell death subroutines: recommendations of the Nomenclature Committee on Cell Death 2012. Cell Death Differ 2012, 19(1):107-120.

31. Hammill AK, Uhr JW, Scheuermann RH: Annexin V staining due to loss of membrane asymmetry can be reversible and precede commitment to apoptotic death. Exp Cell Res 1999, 251(1):16-21.

32. Geske FJ, Lieberman R, Strange R, Gerschenson LE: Early stages of p53induced apoptosis are reversible. Cell Death Differ 2001, 8(2):182-191.

33. Wang K, Brems JJ, Gamelli RL, Ding J: Reversibility of caspase activation and its role during glycochenodeoxycholate-induced hepatocyte apoptosis. J Bio Chem 2005, 280(25):23490-23495.

34. Tang HL, Yuen KL, Tang HM, Fung MC: Reversibility of apoptosis in cancer cells. Br J Cancer 2009, 100(1):118-122.

35. Green DR, Beere HM: Apoptosis. Mostly dead. Nature 2001, 412(6843):133-135.

36. Vaux DL, Silke J: IAPs, RINGs and ubiquitylation. Nat Rev Mol Cell Biol 2005, 6(4):287-297.

37. Salvesen GS, Duckett CS: IAP proteins: blocking the road to death's door. Nat Rev Mol Cell Biol 2002, 3(6):401-410.

38. Vassilev LT, Vu BT, Graves B, Carvajal D, Podlaski F, Filipovic Z, Kong N, Kammlott $U$, Lukacs C, Klein C: In vivo activation of the p53 pathway by small-molecule antagonists of MDM2. Science 2004, 303(5659):844-848.
39. Moll UM, Petrenko O: The MDM2-p53 interaction. Mol Cancer Res 2003, 1(14):1001-1008.

40. Bonni A, Brunet A, West AE, Datta SR, Takasu MA, Greenberg ME: Cell survival promoted by the Ras-MAPK signaling pathway by transcription-dependent and -independent mechanisms. Science 1999, 286(5443):1358-1362.

41. Du KY, Montminy M: CREB is a regulatory target for the protein kinase Akt/PKB. J Biol Chem 1998, 273(49):32377-32379.

42. Yan C, Lu D, Hai T, Boyd DD: Activating transcription factor 3, a stress sensor, activates p53 by blocking its ubiquitination. EMBO J 2005, 24(13):2425-2435

43. Mashima T, Udagawa S, Tsuruo T: Involvement of transcriptional repressor ATF3 in acceleration of caspase protease activation during DNA damaging agent-induced apoptosis. J Cell Physio/ 2001, 188(3):352-358.

44. Villunger A, Michalak EM, Coultas L, Mullauer F, Bock G, Ausserlechner MJ, Adams JM, Strasser A: p53- and drug-induced apoptotic responses mediated by $\mathrm{BH} 3$-only proteins puma and noxa. Science 2003 302(5647):1036-1038.

45. Beckerman R, Prives C: Transcriptional regulation by p53. Cold Spring Harb Perspect Biol 2010, 2(8):a000935.

46. Wang JM, Chao JR, Chen WH, Kuo ML, Yen JY, Yen HFY: The antiapoptotic gene $\mathrm{mcl}-1$ is up-regulated by the phosphatidylinositol 3-Kinase/Akt signaling pathway through a transcription factor complex containing CREB. Mol Cell Biol 1999, 19(9):6195-6206.

47. Gong LJ, Li YW, Nedeljkovic-Kurepa A, Sarkar FH: Inactivation of NF-kappa $B$ by genistein is mediated via Akt signaling pathway in breast cancer cells. Oncogene 2003, 22(30):4702-4709.

48. Li Y, Sarkar FH: Inhibition of nuclear factor kappaB activation in PC3 cells by genistein is mediated via Akt signaling pathway. Clin Cancer Res 2002, 8(7):2369-2377.

49. Nelson EC, Evans CP, Mack PC, Devere-White RW, Lara PN Jr: Inhibition of Akt pathways in the treatment of prostate cancer. Prostate Cancer Prostatic Dis 2007, 10(4):331-339.

50. Seol DW: Up-regulation of IAPs by PI-3K: a cell survival signal-mediated anti-apoptotic mechanism. Biochem Biophys Res Commun 2008, 377(2):508-511.

51. Stehlik C, de Martin R, Kumabashiri I, Schmid JA, Binder BR, Lipp J: Nuclear factor (NF)-kappaB-regulated X-chromosome-linked iap gene expression protects endothelial cells from tumor necrosis factor alpha-induced apoptosis. J Exp Med 1998, 188(1):211-216.

52. Ogawara Y, Kishishita S, Obata T, Isazawa Y, Suzuki T, Tanaka K, Masuyama N, Gotoh Y: Akt enhances Mdm2-mediated ubiquitination and degradation of p53. J Biol Chem 2002, 277(24):21843-21850.

53. Mayo LD, Donner DB: A phosphatidylinositol 3-kinase/Akt pathway promotes translocation of Mdm2 from the cytoplasm to the nucleus. Proc Natl Acad Sci USA 2001, 98(20):11598-11603.

54. Li M, Zhang Z, Hill DL, Chen XB, Wang H, Zhang RW: Genistein, a dietary isoflavone, down-regulates the MDM2 oncogene at both transcriptional and posttranslational levels. Cancer Res 2005, 65(18):8200-8208.

55. Nakamura Y, Yogosawa S, Izutani Y, Watanabe H, Otsuji E, Sakai T: A combination of indol-3-carbinol and genistein synergistically induces apoptosis in human colon cancer HT-29 cells by inhibiting Akt phosphorylation and progression of autophagy. Mol Cancer 2009, 8:100.

56. Manning BD, Cantley LC: AKT/PKB signaling: navigating downstream Cell 2007, 129(7):1261-1274.

57. Testa JR, Tsichlis PN: AKT signaling in normal and malignant cells. Oncogene 2005, 24(50):7391-7393.

doi:10.1186/1475-2867-13-63

Cite this article as: Xie et al.: Genistein promotes cell death of ethanolstressed HeLa cells through the continuation of apoptosis or secondary necrosis. Cancer Cell International 2013 13:63. 